\title{
CATHOLIC COUNTER-REFORMATION: A HISTORY OF THE JESUITS' MISSION TO ETHIOPIA 1557-1635
}

\author{
Elias Kiptoo Ngetich \\ Moi University, Kenya \\ kiptooelias@gmail.com
}

\section{ABSTRACT}

The Jesuits or 'The Society of Jesus' holds a significant place in the wide area of church history. In histories of Europe to the reformation of the sixteenth century, the Jesuits appear with notable frequency. Jesuits were the finest expression of the Catholic Reformation shortly after the Protestant reform began. The Society is attributed to its founder, Ignatius of Loyola. As a layman, Ignatius viewed Christendom in his context as a society under siege. It was Christian duty to therefore defend it. The Society was formed at a time that nationalism was growing and papal prestige was falling. The Jesuits, as a missionary movement at a critical period in the Roman Catholic Church, used creative strategies that later symbolised the strength of what would become the traditional Roman Catholic Church for a long time in history. The strategies involved included, but were not limited to: reviving and nurturing faith among Catholics, winning back those who had become Protestants, converting those who had not been baptised, training of the members for social service and missionary work, and establishing educational institutions. Their mission expansion to other parts of the world, Africa included, was an attempt to compensate the lost grounds in Europe in view of this paper's thesis.

Keywords: Jesuits; Ignatius of Loyola; Roman Catholic Church; Ethiopia

\section{INTRODUCTION}

The Jesuits or 'The Society of Jesus' holds a significant place in the wide area of church history. Mark Noll, citing John Olin, notes that the founding of the Jesuits was 'the most powerful instrument of Catholic revival and resurgence in this era of religious

\section{UNISA $\cong$}


crisis'. ${ }^{1}$ In histories of Europe to the Reformation of the sixteenth century, the Jesuits appear with notable frequency. The Jesuits were the finest expression of the Catholic Reformation shortly after the Protestant reform began. The Society is attributed to its founder, Ignatius of Loyola. As a layman, Ignatius viewed Christendom in his context as a society under siege. It was Christian duty to therefore defend it. The Society was formed at a time that nationalism was growing and papal prestige was falling. As Christopher Hollis observed: 'Long before the outbreak of the great Reformation there were signs that the unity of the Catholic Christendom was breaking up. ${ }^{2}$ The Jesuits, as a missionary movement at a critical period in the Roman Catholic Church, used creative strategies that later symbolised the strength of what would become the traditional Roman Catholic Church for a long time in history. The strategies involved included, but were not limited to: reviving and nurturing faith among Catholics, winning back those who had become Protestants, converting those who had not been baptised, training of the members for social service and missionary work, and also establishing educational institutions.

As Noll observes: 'Although there would be many sources and influences contributing to the Catholic Counter-Reformation, the Jesuits would be the most remarkable in winning Protestant regions back to Rome and, even more, for solidifying the faith of those in Europe who wavered in their loyalty to the Catholic Church. ${ }^{3}$ In the thesis of this paper, their mission expansion to other parts of the world, Africa included, was an attempt to compensate for the lost grounds in Europe. By the time the Jesuits were moving out in mission endeavours, a third of Europe had leaned towards Protestantism. Key Protestant reformers after the death of Martin Luther had at this period completely parted ways with the Catholic Church and were busy grounding Reformation across Europe. Although Protestants had historically not recognised Catholic missionary activity in the sixteenth century, the record of the Jesuits' work beyond the Mediterranean displays remarkable faithfulness to Christianity. Catholic missionary movement in Africa began three and a half centuries before the Protestant mission movement began in the late seventeenth century.

The Jesuits were among the first Roman Catholic religious Orders to go out for missions beyond the Mediterranean. Not only did the Jesuits shape Roman Catholicism for nearly half a millennium, they also illustrated the possibilities and problems that came along as Euro-centred Christianity sought to missionise other parts of the world. The Jesuits' mission to Ethiopia was a micro demonstration of how the Roman Catholic Church had become a different body in the sixteenth century from what it was a century before. As it sought to reform herself, the Roman Catholic Church worked its reforms internally: 'The clearest instance of reform as

1 Mark A. Noll. Turning points: Decisive moments in the history of Christianity. (Grand Rapids, Michigan: Baker Books, 1997), 201.

2 Christopher Hollis. The Jesuits: A history. (New York: The Macmillan Company, 1968), 6.

3 Noll, 1997, 201. 
an internal movement was the great surge in creating new religious Orders that dated from the 1520s.' ${ }^{4}$ The Jesuits was one such a movement.

\section{IGNATIUS LOYOLA}

Ignatius Loyola was from northern Spain. He was most probably born in 1491, in the Basque province of Guipuzcoa. He was a soldier who was wounded in a siege at Pamplona, and could therefore not continue in his chosen profession as a soldier. In his time of isolation, prayer and meditation in a monastery, Ignatius went through spiritual conflict. He adopted a disciplined spiritual life and ended up establishing an organisation with strong spiritual discipline in the Roman Catholic Order. His Order came to be known as the 'Society of Jesus' or the Jesuits. In his book, The Jesuits: $A$ history of the Society of Jesus from its foundation to the present time, Thomas J. Campbell (S.J.) asserts that: 'As far as we are aware...Ignatius never used the term Jesuit at all. He called his Order the Compania de Jesus... a reminiscence of Loyola's early military life', and which meant 'a battalion of light infantry, ever ready for service in any part of the world' . ${ }^{5}$ The Jesuit Order, by and large, saw their calling and duty as defenders of Christendom and papal prestige that was first falling due to Protestant Reformation and the growing of nationalism. For many centuries, it was seen as the Roman Catholics' spiritual battalion.

The Jesuits differed from the other Orders in various external ways as well. They did not wear a distinctive habit; they were not cloistered; and consequently they did not chant the liturgy or participate in communal prayer of any kind. Ignatius also intended to break away from the old monastic tradition of scholarship. In the first draft of the statutes of the Order the following notation is found: '...neither studies nor reading aloud in the Society of Jesus.' ${ }^{6}$ However, the pursuit and transmission of knowledge became one of the Order's main concerns. At the time of Loyola's death, there were already 29 Jesuit academies in existence. There were four basic organisational differences that distinguished them from the other Orders. First, the compania was to be headed by a Superior General. The second one involved the well-known fourth vow, "we pledge ourselves to obey every instruction of the Pope of Rome, to go in whatsoever direction he might choose to send us...Even if this takes us among the Turks or any other infidels...' 7 The third organisational difference is that a Jesuit was expected to remain a Jesuit and not to accept any other ecclesiastical office or any higher rank that is not bestowed by the Order. The final and fourth difference was the Jesuits' work not being restricted to the parish and the

\footnotetext{
4 Ibid, 202.

5 Thomas J. Campbell (S.J.). The Jesuits 1534-1921.(New York: The Encyclopedia Press, 1921),7.

6 Manfred Barthel. The Jesuits' history and legend of the Society of Jesus (New York: William Morrow and Company, 1984), 22.

7 Ibid.
} 
pulpit. The boundaries of the Jesuits' parish extended to wherever the influence of the church was needed.

Loyola was greatly influenced by the works of Thomas Kempis, especially The imitation of Christ, along with other works. He took a vow of chastity and poverty and began to live a very ascetic life. He is known to have fasted, prayed, cared for the sick and begged for his food. This was working out of his spiritual discipline, which to many was a military discipline adapted to the spiritual life. Loyola was a layman when he founded the Jesuits. He went to the University of Paris between 1528 and 1535. He was a contemporary of John Calvin. At the University of Paris, he gathered a group of young men whom he mentored. They were: Pierre Farve, Francis Xavier, Nicholas Boabdilla, Simao Rodriguez, Diego Lainez, and Salmeron Alonso. ${ }^{8}$

The first of Ignatius's companions was Pierre Farve who was born in 1506 to a Savoryard peasant. He ended up being one of the leaders of the infant Jesuit Order. Francis Xavier was born in Navarre in 1506. It is said that Xavier was a 'goodlooking, pleasure loving undergraduate'. Ignatius 'finally wore down his resistance by tirelessly sounding that favorite theme of the sixteenth-century moralists - the emptiness of the pleasures of the flesh, the transitory of all worldly things' ${ }^{9}$ Not only did Xavier receive Ignatius's message, he ultimately became 'the Apostle to the Indies'; the first and most successful of the Jesuit missionaries to India and Japan and was canonised by the Roman Catholic Church. ${ }^{10}$ The third member of Ignatius's circle was Nicholas Boabdilla, a Spaniard born in 1509. He had a fairly irritable character and it is said that on one occasion Ignatius had to recall him from a mission to Germany because his unpleasant manner had already made too many enemies. He ended up living longer than his comrades and he died in 1590, at the age of 81. Simon Rodriguez, a Portuguese, was born in 1510. The youngest in the group, a Spaniard Alfonso Salmeron, was born in 1512. The two played more distinctive roles in the early history of the Order. Bartel notes that: 'Salmeron's name is even mentioned in the archives of the Elizabethan secret service, since informers had identified him as one of the organisers of the Catholic underground in England. ${ }^{11}$ The sixth was Diego Lainez, Ignatius's personal friend, who was born in 1512 in Spain. Shortly before his death Ignatius chose Lainez to succeed him as General of the Order, which he did well.

On 15 August 1534, the year that Calvin converted (not on the same date), Loyola and his companions, ranging in age from 18 to 26, moved from the Latin Quarter to the Hill of Montmartre, where they took a vow of poverty and chastity. It was also at the same time that they formed the Society of Jesus. After taking vows,

8 William V Babgert (S.J.). A history of the Society of Jesus. (St. Loius: The Institute of Jesuit Sources, 1986), 16.

9 Barthel, 1984, 32.

10 Ibid, 33.

11 Ibid, 34. 
they were determined to go to the holy land as missionaries or wherever the Pope would send them. Montmartre was chosen because it was the poorest neighbourhood in Paris. 'The municipal gallows was located on the crest of the hill, which tended to keep rents low. ${ }^{12}$

In 1540, six years after its formation, Pope Paul III approved the Society as an Order, an army of the church. In 1560, 20 years later, Pope Julius III confirmed the Society in the bull Exposcit debitum. ${ }^{13}$ Soon the members of the Society became known us Jesuits - those peculiarly associated with the name of Jesus - at first in a pejorative sense. Their vow was to be: 'Obedient to the Pope for the good of souls and propagation of the faith whether to Turks or other infidels, to India, to lands of heretics, schismatic (Protestants) or faithful Christians. ${ }^{14}$ Pope Paul III began to use some of the Society's members outside Rome as from 1539. In October 1540, Pierre Favre was directed to accompany doctor Pedro Ortiz of the emperor's diplomatic corps into Germany for the religious debates between Catholics and Protestants scheduled at Worms and Regensburg. As the first Jesuit to enter Germany, Fevre 'reached the conclusion that the people of that country were not turning to Lutheranism because of any logic of doctrine but because of the widespread breakdown of Catholic life, even among clergy'. ${ }^{15}$ The Society of Jesus' contribution in Germany led to the restoration of their ancient religious heritage at Worms, Speyer and Regensburg.

The Society's expansion was fast. In 1540 the Society numbered 10; by 1556 , the year Ignatius died, about 1000 . The expansion majorly took educational form where preaching, teaching and catechism was part of it. Residences in university towns were set up where the scholastics would follow the courses in the schools. By 1544 there were seven such residences in Europe. In 1545 Francis Borgia, one of the most eminent Jesuits, founded at Gandia a college for the training of Jesuit scholastics. Under the advice of Xavier, the Jesuits established its first schools in Europe, Messina. In the eight years between 1548, when Messina College was opened, until 1556, the year of Ignatius's death, Ignatius started in Europe 33 schools for secular students and gave approval for the opening of six others. ${ }^{16}$ During its first century, the Society of Jesus played an important role in the Counter Reformation, which brought new vigour to the Roman Catholic Church in Europe. One of its principal means of doing so was through education. In 1579 the Jesuits administered 144 colleges; by 1749 this number had grown to 669 colleges and 24 universities. ${ }^{17}$ The curriculum emphasised rhetoric, communication skills, philosophy, and theology.

12 Ibid, 34.

13 Ibid, 22.

14 Kenneth S. Latourette. A history of Christianity (San Francisco: Harper-San, 1975), 847.

15 Babgert 1986, 23.

16 Ibid, 28.

17 Christopher Chapple, Ed. The Jesuit tradition in education and missions: A 450 year perspective. (Scranton: University of Scranton Press, 1993), 7. 
Among many places that the Jesuits went, Africa was one of them. Their presence in Africa can be traced back to the 1500 s.

\section{THE JESUITS' HISTORIOGRAPHY IN AFRICA}

The Jesuits in Africa have received scant attention from historians and other scholars. This paper, in a small way, attempts to correct this oversight. Xavier visited Mozambique in 1541; significant sources claim that Jesuit involvement has spanned a 450-year period, including missions in Abyssinia (Ethiopia), the Congo (Zaire, Kwango, Angola), the Zambezi (Zimbabwe), the Sudan, and other places. Although the concentrated activities of the Jesuit missionary activity can be described regarding four separate regions in Africa over the 450 years, the focus of this paper will majorly concentrate on Ethiopia. The rationale is Ethiopia's historical significance to early Christianity in Africa and the fact that, politically, Ethiopia was never colonised.

The Jesuits' history of missionary achievements in Africa remained in the background for a long time. Scholars and historians in this period were more attracted by the military expedition led by Vasco da Gama in 1541-43. A turning point on the Jesuits historiography came in the turn of the twentieth century. Between 1902 and 1917 the Jesuit, Camillo Beccari, edited 15 volumes of documents from the Jesuit mission. ${ }^{18}$ Beccari's collection made accessible to the wider public most of the Jesuit and Portuguese sources. The collection had a noticeable impact within the wider Jesuit community and among those interested or involved in one way or another in the Horn of Africa. In the following decades there ensued an important number of articles, mostly in colonial or Jesuit-related publications. Although there are earlier examples in the biographies provided by the seventeenth-century Jesuit, Antonio Franco, it is during these years when biographical notes dedicated to some missionaries began to make their way into encyclopaedias and historical dictionaries. ${ }^{19}$

Judged from today's historiographical standards, the production during these years has had an important value. ${ }^{20}$ Some studies had a clear hagiographic purpose. Others were little more than pamphlets blaming the missionaries for their missiological failures. Using Jesuit sources, some researchers attributed the failure of the Jesuit enterprise to the intolerance shown by the missionaries. More recently, the Ethiopian scholars Girma Beshah and Merid Wolde Aregay made a concise but valuable contribution by working on both Ethiopian and Portuguese sources. ${ }^{21}$ Their

18 Leonardo Cohen Shabot and Martínez D.Alòs-moner. The Jesuit Mission in Ethiopia $\left(16^{\text {th }}-17\right.$ th Centuries): An analytical bibliography. In Aethiopica 9, 2006, p. 192.

19 Ibid, 193.

20 Leonardo Cohen Shabot and Martínez D.Alòs-moner, 2006, 192.

21 Ibid, 192. 
studies have a marked analytic character, displaying a more critical approach to Ethiopian, Portuguese and Jesuit sources.

\section{A BRIEF HISTORY OF ETHIOPIA}

The book of Isaiah in the Bible depicts Ethiopia thus: 'Woe to the land shadowing with wings, which is beyond the rivers of Ethiopia; that sendeth ambassadors by the sea, even in vessels of bulrushes upon the waters...' (Isaiah 18:1-2). Ethiopia is an ancient country located in north-east Africa. It is bordered by Sudan in the west, Eritrea in the north and north east, Kenya in the south, Somali in the south east, and Djibouti in the east. Early in the fourth century AD the word Ethiopia, taken from Greek and formerly used to designate the Cushite kingdom (Sudan), began to be employed by the Aksumite kings to refer to their own country. The term Ethiopia was a generic term used in classical times to refer to or designate the African landmass to the south of Egypt. ${ }^{22}$ Christianity emerged in Ethiopia in the mid-fourth century. Christianity was imported into the country during the reign of Ezana. ${ }^{23}$ Ezana is recounted by a number of ecclesiastical historians, the earliest being Rufinus of Aquila (c AD 345-410). Athanasius, patriarch of Alexandria is said to have consecrated Frumentius as bishop of Aksum. 'This instituted the tradition, which entered ecclesiastical law, that the Alexandrian patriarchs should appoint the metropolitan bishops of Ethiopia. ${ }^{24}$ This tradition is said to have lasted for long; it was until in the 1950s when the first Ethiopian was appointed to the post.

The Aksumite Empire is the power that Ethiopia is often identified with. Paul B. Henze, quoting the Persian prophet Mani, says: 'There are four great kingdoms on earth: first is the Kingdom of Babylon and Persia; the second is the Kingdom of Rome; the third is the Kingdom of the Aksumites: the fourth is the Kingdom of the Chinese. ${ }^{25}$ This is an indication that the Aksumite Empire was well known in the ancient world right from Rome to as far as ancient China. Henze laments that the Aksumite Empire was forgotten in Medieval Europe. All that persisted was the legend of Prester John. From the middle of the fourth century until the present, the highland Christian civilisation has been the characteristic part of Ethiopia, which differentiated the northern part from its African neighbours. Aksum maintained its control over the Ethiopian highlands in the north from about the first to the seventh centuries AD. Historical details about the Aksum period are scanty. Aksum adoption of Christianity did not cease with the city ending from being a political centre of the land. Aksum itself declined but never stopped to exist. It remained a political

22 Bahru Zewde. A history of Modern Ethiopia 1855-1991. (Addis Ababa: Addis Ababa University Press, 2001), 1.

23 Stuart Munro-Hay. Ethiopia, the unknown land:A cultural and historical guide. (New York: I.B. Tauris Publishers, 2002), 20.

24 Ibid.

25 Paul B. Henze. Layers of time: A history of Ethiopia. (New York: Palgrave, 2004), 22. 
and religious symbol. This Ethiopian kingdom maintained its Christian faith. The reign of emperor Kaleb in the sixth century marked the final period of Aksumite expansion under the banner of Christianity and in the context association with it. Aksum declined in the middle of the seventh century due to the influence of Islam.

The Ethiopian Christianity that came out of the Aksumite context was a unique African church. It was deeply rooted in Ethiopian history, social life and ethics. It preceded the formation and development of Christianity in the West. While the Ethiopian Church was closely connected to both the Coptic Church of Egypt and the Byzantine Christianity, it developed its own liturgy, educational system for clergy and laymen, monastic tradition, religious music, and an extensive tradition of commentary and exegesis of the Bible. These elements contributed to the formation of a distinct domain of Ethiopian Christian religious identity.

In the sixteenth century, the Portuguese were expanding their explorations, their commerce and their conquest in the east at a rapid rate. They knew, or thought that they knew, of a mysterious Christian ruler in the east popularly known then as Prester John of the Indies. By the 1400s, Italian, Portuguese and other explorers were yet to identify a suitable candidate for Prester John in the Solomonic king of kings of Ethiopia. Portugal particularly cemented fairly close relations with Ethiopia in the period that followed. A first Portuguese envoy was to be sent in 1487; and the one who arrived in 1493 was Pero de Covilham. Other envoys followed in 1508. They thought that finding and identifying Prester John was important. Then with his aid, Islam could be rooted out. But this never became the case. Prester John became a legend who ruled a mysterious Christian empire somewhere beyond the boundaries of the known world. Some placed it in Africa, others in Asia. Muslim incursions destroyed much of the Christian kingdom. During this period, however, the royal chaplain Fransico Alveres compiled an important record of the embassy with descriptions of places, people and customs that he saw in Ethiopia. These records helped in opening up Ethiopia to the outside world. The missionaries, many of them Portuguese sent via Goa, compiled detailed notes on almost every facet of Ethiopian life. This became a new age for Ethiopian historiography. A Portuguese army contingent led by C. da Gama, was sent by the Portuguese king to help a fellow Christian monarch in trouble against the violent expansion under the Islamists.

\section{THE JESUITS IN ETHIOPIA}

Even before Pope Paul III had granted the final and official approval of the Society of Jesus in 1540, the Pope had sought Ignatius's help in responding to a request he had received from John III, King of Portugal. The king wanted to send Jesuits to his colony of Goa on the west coast of India. Xavier was selected for the task and he sailed from Lisbon on 7 April 1542. In August 1541, the ship carrying Xavier arrived in Mozambique, thus making him the first Jesuit in Africa. There he taught 
Christian doctrine, cared for the sick and provided sacraments. The only recorded meeting between Xavier and an African is described in his own letter from Goa to his brothers of the Society at Rome, dated 18 September $1542 .{ }^{26}$ Sailing north along the Swahili coast of what is now Tanzania and Kenya, Xavier was moved by the sight of a Portuguese cross placed there by Vasco da Gama a half-century earlier. The missionary aspect of Xavier's meeting an African in Africa was his assertion that 'Christians are right and all others are wrong'. ${ }^{27}$

The years 1550 to 1633 witnessed a persistent attempt to establish the Roman Catholic Church in Ethiopia. ${ }^{28}$ The first permanent mission was started in 1557 under Bishop Orviedo. Abyssinia, or Ethiopia, was an African country that was known even before the coming of the Jesuits. This was known by Ignatius and Jesuit brothers through the writings of Alvares and Piefro, an Ethiopian monk residing in Rome since $1540 .{ }^{29}$ Ignatius was personally involved in the preparations to send the first Jesuit missionaries to Abyssinia - or what is now known as Ethiopia. It was John III, King of Portugal, who suggested that a Jesuit be consecrated for the purpose. Ignatius did not dissent and in 1555 three Jesuits were consecrated: Nunez Baretto, Oviedo and Camero; Nunez being their patriarch. ${ }^{30}$ In their preparation to minister in Ethiopia, the first Jesuits were urged to uphold the principle of toleration, especially of the Jewish inheritance. This was because they were doing mission among Christian people. Changes acceptable to Roman Catholics were to be introduced gradually. Ignatius also recognised the necessity for missionaries to provide care for the temporal as well as spiritual welfare of the people. The mission to Ethiopia, even with much preparation, was not a success. Bishop Baretto died in Goa in 1562 without ever visiting his diocese. Turkish military activity in the Red Sea area prevented any support from reaching the Jesuits, who were isolated in Abyssinia. The hostility within this context limited the Jesuits' ministry to only the Portuguese community in the country. The Society considered withdrawing its members from the country, but Pope Gregory XIII could not allow this. The Pope's concern and fear was losing the Christian country to the Muslim world.

It was not until the arrival of Father Peter Paez that Roman Catholicism made any progress. Paez, who lived in Ethiopia from 1603 to 1622, was not only a staunch missionary but a builder and architect as well, and his ability along these lines proved to be very useful. ${ }^{31}$ Paez was 'A remarkable linguist who soon learned to read and write Ge'ez and Amharic, he converted the king, Susenyos, and some of his

26 Ibid, 256.

27 Ibid, 257.

28 Dale H. Moore. Christianity in Ethiopia. In Church History 5(3) September, 1936, pp. 279, www. jstor.org (accessed 10 November 2012).

29 Ibid.

30 Henze. Layers of time: A history of Ethiopia, 258.

31 Moore. Christianity in Ethiopia. http://www.jstor.org, page 279 (accessed 11 October 2012). 
kinsmen and courtiers'. ${ }^{32}$ Susenyos openly declared himself a Catholic in 1622, the same year that Paez died. Paez had had significant positive impact. He was tactful in dealing with the Ethiopians. He came to have profound influence upon the Emperor, Za Dengel, to such an extent that the latter declared himself in favour of the Roman Catholic religion. Paez's successor, lacking his tact and wisdom, opposed cultural practices that were neutral and insisted on the Latin calendar and liturgy. Disguised as an Armenian merchant, he made his way to the Ethiopian emperor's court. His mission concentrated on the court, nobles, and persons of influence.

The man chosen as patriarch of those who succeeded Paez, was Alfonzo Mendez. It was unfortunate for Mendez that a great plague of locusts visited Ethiopia the year of his arrival, and the Ethiopian priests were not slow in associating the two events in the minds of the superstitious people. Mendez took advantage of this opportunity. While the emperor had publicly confessed Roman Catholicism in 1622, the patriarch decided that this should be done again in the most impressive fashion. On 11 February 1626, the emperor, his family and the court made full and complete submission to the authority of the Roman Church and its papal representative. ${ }^{33}$ This absolute surrender infuriated the priests of the Ethiopian Church and the people who were loyal to it. If Mendez had been content to develop his success more carefully, all might have gone well for the Roman cause. But he persuaded the king to pass a set of the most intolerant laws against those who would not conform to the new religion, making them the enemies of the empire. In spite of growing opposition, the Roman power continued strong at court for three years.

The emperor was strong to defeat those who rebelled against him, but only at the cost of many lives. Though he became victorious in battle, the enemies of the Jesuits continued to fight on. Finally, Susenyos became disheartened and unhappy because of the continual bloodshed and, in 1631, issued a proclamation permitting everyone to follow his own religious inclinations. This edict of toleration angered Mendez and he forced the king to change it. That caused further rebellion. Everyone was opposed to the emperor; even his own son turned against him. Wearied with the long and useless struggle, Susenyos, in 1632, abdicated in favour of his son Fasilides, proclaiming at the same time that the old religion could be restored. Fasilides was strongly antiJesuit and immediately set about the task of restoring the Ethiopian Church to its former authority and of driving the Jesuits out of the country. Mendez, seeing that his cause was practically lost, made many concessions. But it was too late; Ethiopia did not want Roman Catholicism in any form. The Jesuits were expelled from Ethiopia in 1632. In 1635 Mendez was forced to leave the country. The other Jesuit priests were asked to leave Ethiopia and those who would not go were killed. By 1633 the persecution of Catholics and the exclusion of foreigners sealed off Ethiopia from the

32 Elizabeth Isichei. A history of Christianity in Africa: From antiquity to the present. (Grand Rapids, Michigan: Eerdmans, 1995), 51. 
West for the next century and a half. After nearly 150 years, Europeans were to leave Ethiopia alone in the isolation forced upon it by the Muslims who surrounded the country. With small encouragement, Roman Catholic missionary activity persisted throughout the eighteenth and nineteenth centuries. The suppression of the Society of Jesus by Pope Clement XIV in 1773 led to an interruption of Jesuit missionary activity throughout the world. The Society was restored in 1884 by Pope Pius VII.

\section{CONCLUSION}

The Jesuit experience provides many lessons for contemporary missiology: the need to respect cultures; the shape of communication; and the importance of learning as well as teaching. From the foregoing study, it seems clear that the Jesuits preferred to disseminate Catholicism from top to bottom. The Jesuits worked intensively amongst the Ethiopian nobility, attempting to form alliances with emperors and governors. They provided them with religious services and served as mediators and messengers in negotiations with hostile populations. Moreover, the Jesuit missionaries aspired to overtake the Ethiopian ecclesiastical hierarchy. They did this by trying to sever the traditional connection to the Alexandrian Coptic Church and replace it with ties to the Roman Catholic Church. Their approach included seeking to always replace the leadership of the powerful monasteries, influential in internal ecclesiastical politics, with leaders who acted in favour of Catholicism. This was not always a success story. Furthermore, as of 1624, upon the arrival of Catholic patriarch Afonso Mendez to Ethiopia, local Catholic clergy began to be appointed in order to propagate the new religion more effectively. The Jesuits believed that gaining control over key positions of power was the right formula for success.

The main cause of failure in establishing Catholicism in Ethiopia was the Jesuit missionaries' attempts to create a religious system which would be homogeneous in terms of creed and theology, as well as in terms of rituals. As in the case of the Catholic Reformation in Europe, the Jesuits wished to sacrifice the local religious expressions for the benefit of a uniform, standardised religion; with versions clear and acceptable to the entire Catholic public. It is true that the Jesuits assimilated many local traditions and managed, with some success, to integrate EuropeanCatholic and Ethiopian elements; that was done for example in Masses, processions and displays. However, the aspiration for coherent Catholicism, with ritual and theological uniformity, met a society consisting of those who simply refused to absorb the centralism which the Jesuits represented in political terms as well as in respect of religion, rituals and creeds. Despite the largely unsuccessful missionary activities of the Jesuits in Ethiopia, it must be acknowledged that the Jesuits had indeed contributed significantly in developing the Ethiopian historiography. 


\section{REFERENCES}

Babgert ,W.V. (S.J.) 1986. A history of the Society of Jesus. St. Loius: The Institute of Jesuit Sources.

Bahru, Z. 2001. A history of modern Ethiopia 1855-1991. Addis Ababa: Addis Ababa University Press.

Barthel, M. 1984. The Jesuits' history and legend of the Society of Jesus. New York: William Morrow and Company.

Campbell, T.J. (S.J.) 1921. The Jesuits 1534-1921. New York: The Encyclopedia Press.

Chapple, C. (Ed.). 1993. The Jesuit tradition in education and missions: A 450 year perspective. Scranton: University of Scranton Press.

Cohen, L. 2006. The Jesuit Mission in Ethiopia (16 $6^{\text {th }}-17^{\text {th }}$ centuries): An analytical bibliography. Aethiopica 9.

Henze, P.B. 2004 Layers of time: A history of Ethiopia. New York: Palgrave.

Hollis, C. 1968. The Jesuits: A history. New York: The Macmillan Company.

Isichei, E. 1995. A history of Christianity in Africa: From antiquity to the present. Grand Rapids, Michigan: Eerdmans.

Latourette, K.S. 1975. A history of Christianity. San Francisco: Harper-San.

Moore, H.D. 1936. Christianity in Ethiopia. Church History 5(3), www.jstor.org (accessed 10 November 2012).

Munro-Hay, S. 2002. The unknown land: A cultural and historical guide. New York: I.B. Tauris Publishers.

Noll, A.M. 1997. Turning points decisive moments in the history of Christianity. Grand Rapids: Michigan: Baker Books. 